\title{
OPTIONS LISTING AND THE VOLATILITY OF THE UNDERLYING ASSET: A STUDY ON THE DERIVATIVE MARKET FUNCTION
}

\author{
Marc Chesney \\ Economy and Finance Department Professor and \\ Associate Dean of the Doctorate Program at HEC (Hautes \\ Études Commerciales Jouy en Josas), France. \\ E-mail chesney@gwsmtp.hec.fr \\ William Eid Júnior \\ Accounting, Finance and Control \\ Department Professor at EAESP/FGV. \\ E-mail weid@eaesp.fgvsp.br
}

RESUMO: Os mercados de derivativos são vistos com muita desconfiança por inúmeras pessoas. Este trabalho analisa o efeito da introduçāo de opçōes sobre açōes no mercado brasileiro buscando identificar uma outra justificativa para a existência destes mercados: a alteração no nivel de risco dos ativos objetos destas opçōes. A evidēncia empírica encontrada neste mercado está de acordo com os resultados obtidos em outros mercados - a introdução de opçōes é benéfica para o investidor posto que reduz a volatilidade do ativo objeto. Existe também uma tênue indicação de que a volatilidade se torna mais estocástica com a introduçāo das opçōes.

ABSTRACT: There are basic misunderstandings on derivative markets. Some professionals believe that they are a kind of casinos and have no utility for the investors. This work looks at the effects of options introduction in the Brazilian market, seeking for another benefit for this introduction: changes in the stocks risk level. Our results are the same found in the US and other markets: the options introduction reduces the stocks volatility. We also found that there is a slight indication that the volatility becames more stochastic with this alternative.

PALAVRAS CHAVE: introdução de opções, volatilidade, GARCH.

KEY WORDS: option introduction, volatility, GARCH. 
The existence and utility of derivative markets, options in particular, have been questioned for a long period of time. Since the crash of the Amsterdam Stock Exchange in 1636, operations in these markets have been regarded as gambling.

In England, for example, options were declared illegal in 1733 by the Barnard Act, which was only revoked in 1860 . However, options were banned again during the 1931 crisis, after World War II, and finally, in 1958. The members of the English Labor Party are particularly critical of options, which, they believe, evidence that stock markets are made for gamblers.

In the United States of America, options were also considered illegal at the end of the $19^{\text {th }}$ century. Only after a long struggle in Congress were they finally approved. The conflict was between Congressmen and public opinion, on one side, and Herbert Filer who spoke on behalf of stockbrokers and emphasised the advantages of operations with options as a type of hedging.

Recently, however, a series of facts has put the derivative market on the spot as a major source of criminal activities such as:

a. the 1987 stock exchange crash;

b. the US $\$ 1,6$ billion loss suffered by German Metalgeselschaft in the futures market;

c. the US $\$ 130$ million loss by Procter \& Gamble in operations with options;

d. the Barnes Bank bankruptcy caused by operations with derivatives by one of its members in Singapore.

The purpose of this study is not to discuss whether the strategies adopted by each of these parties in the financial market were right or wrong, but to show how, to a large extent, they contributed to reinforce all the arguments against derivative markets.

The first question that arises after analysing these cases is whether derivative markets have any use besides speculation and hedging.

It is highly questioned among participants in the financial market whether derivatives affect the volatility of target assets. The issue is in opposing two trends. The first one regards derivatives as, by nature, speculative investments which desestabilize prices in cash markets. The second trend is based on the idea that derivatives, on the contrary, tend to improve the general performance of financial markets allowing for a greater flow of information.

The present study tries to identify changes in the behaviour of the volatility of target assets in options after derivatives are introduced in the market. As the volatility of target assets measures their

It is highly questioned among participants in the financial market whether derivatives affect the volatility of target assets. The issue is in opposing two trends. The first one regards derivatives as, by nature, speculative investments which desestabilize prices in cash markets. The second trend is based on the idea that derivatives, on the contrary, tend to improve the general performance of financial markets allowing for a greater flow of information.

variability and, consequently, their risk, we will try to show how derivatives, when volatility is lowered, can be extremely useful by reducing risks to investors in cash markets. We will also try to analyse the variability of the volatility of the target assets itself, bearing in mind its best modelling.

The present study is organised as follows: Section II describes the data used, Section III the methodology of analysis, Section IV the results obtained and Section $\mathrm{V}$ presents the conclusions, comparing results in Brazil with those of other countries as well as indicating new ways for the research on the subject. 


\section{DATA}

Stock options were initially introduced in Brazil in 1979. Since then they have been negotiated in the São Paulo and the Rio de Janeiro Stock Exchanges. Data were selected following the daily performance of six shares ${ }^{1}$ which have or had options introduced between August 1990 and June 1993. Based on these data series of continuously compounded yields were built. An index was adopted to analyse the effects of volatility variation by calculating the average of daily yields of ten shares which do not have nor never had options ${ }^{2}$.

All data were adjusted as usual to

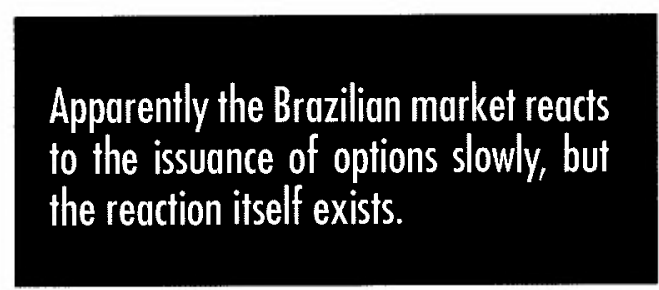

account for shareholders rights. These data, however, have not been deflated since this study compares volatility at the same point in time.

\section{METHODOLOGY}

In order to determine the effect of option's listing on the volatility of the underlying asset the following scheme was devised:

a. we determined the volatility of the target asset.for the six months prior to the introduction of the options and the six months after the options were introduced;

This research have been partially supported by the NPP - Núcleo de Pesquisas e Publicações da EAESP/FGV, Brazil.

1. Banco do Brasil (BB4), Eletrobrás (ELE3 e ELE6), Petrobrás (PET4), Paranapanema (PMA4), Telebrás (TEL4).

2. Sudameris $(B F / 3)$, Banco Noroeste (BNE4), Real de Investimentos (BRI4), Cosigua (COG4), Frigobrás (FRI4), Banco Real (REA3), Siderúrgica Riograndense (Ri04), Sadia Concórdia (SCO4), Tupy (TUP4), Unibanco (UBB3).

c. we determined the excess volatility of the target asset in relation to the market by subtracting from the volatility of the target asset the volatility of the index;

d. the averages of excess volatility for the six months before and after the introduction of the options were compared and a statistic $t$ was established to identify changes in the behaviour of such averages at a $95 \%$ reliability level. The same procedure was adopted for two months before and two months after the introduction. All this procedure was followed for tree different estimates of volatility:

a. an annual historical estimate based on the following formula:

$$
V A=\sqrt{\sum_{i=1}^{n} \frac{\left(u_{i}-u_{m}\right)^{2}}{20}} \cdot \sqrt{251}
$$

where $\mathbf{n}=$ number of observations $u_{i}=$ continuous yield of the option $\mathrm{u}_{\mathrm{m}}=$ continuous yield average $\mathrm{t}=251$ days

b. volatility calculated by the method of extreme values, according to Parkinson (1980):

$V E V=\left[\frac{0.3607}{21} \sum_{i=1}^{21} \ln \left(p_{\max }-p_{\min }\right)^{2}\right] \cdot \sqrt{251}$

where

$$
\begin{aligned}
& \mathrm{p}_{\max }=\text { maximum price of the asset } \\
& \text { per day } \\
& \mathrm{p}_{\min }=\text { minimum price of the asset } \\
& \text { per day } \\
& \mathrm{n}=\text { number of observations }
\end{aligned}
$$

c. conditional volatility estimated determining the conditional variation bases on a GARCH model (1.1):

$$
\begin{gathered}
h_{t}=\alpha_{0}+\alpha_{1} e_{t-1}^{2}+\beta h_{t-1}+e_{t} \\
V C=\sqrt{h_{t}} \cdot \sqrt{251}
\end{gathered}
$$


recently introduced, has grasped the attention of several researchers. In order to do the analysis we calculated the historical volatility of each of the three volatilities already presented based on the following formula:

$$
V V=\sqrt{\sum_{i=1}^{n} \frac{\left(v_{i}-v_{m}\right)^{2}}{n-1}} \cdot \sqrt{251}
$$

where $\mathrm{n}=$ number of observations

$\mathrm{v}_{\mathrm{i}}=$ volatility at the $i$ instant

$\mathrm{v}_{\mathrm{m}}=$ average volatility for the period with $n$ observations.

This analysis allows us to observe the behaviour of one more aspect of the volatility of the underlying asset, which contributes to a better understanding of this parameter, which is of fundamental importance for the participants of several financial markets.

\section{RESULTS}

The results presented on table ${ }^{3} 1$ referring to volatility behaviour should be analysed according to the estimate of volatility used and the period of time studied.

The first period of six months indicates a decrease in volatility of underlying assets in the three estimated volatility cases. Four of the six shares analysed presented a significant decrease in volatility at a $95 \%$ level in all the three methods of estimation applied. The result was interesting because it showed that the risk for the investor decreased when the options were listed.

The results of the two month period are not so clear. There was an increase in the historical volatility of four of the six shares, a decrease in the volatility by extreme values of four of the six shares, and a break-even of conditional volatility, with three shares showing an increase and the other three a decrease.

Apparently the Brazilian market reacts to the issuance of options slowly, but the reaction itself exists.

Table 2 indicates the results obtained in the analysis of the volatility of volatility. The first period of five months ${ }^{4}$ was

\section{TABLE 1}

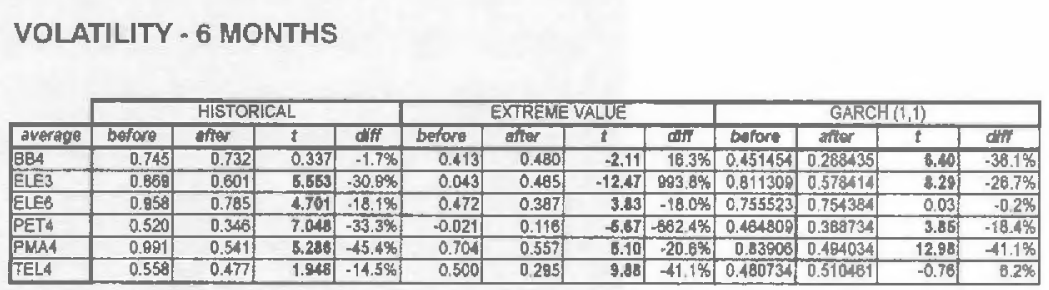

VOLATILITY - 2 MONTHS

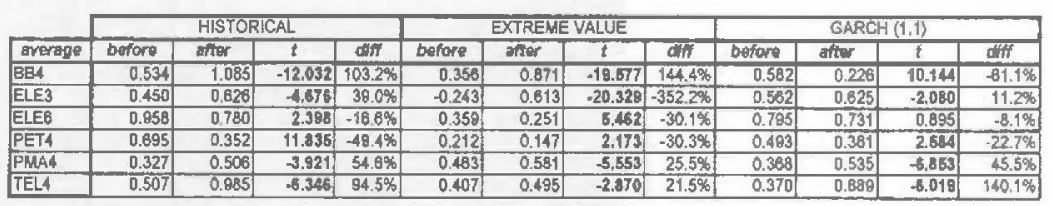

\section{TABLE 2}

\section{VOLATILITY OF VOLATILITY - 5 MONTHS}

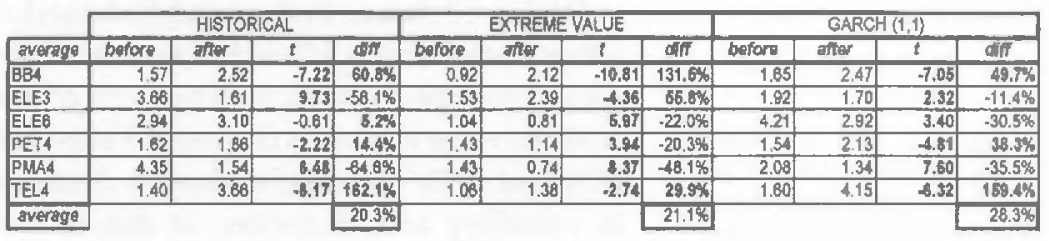

VOLATILITY OF VOLATILITY - 2 MONTHS

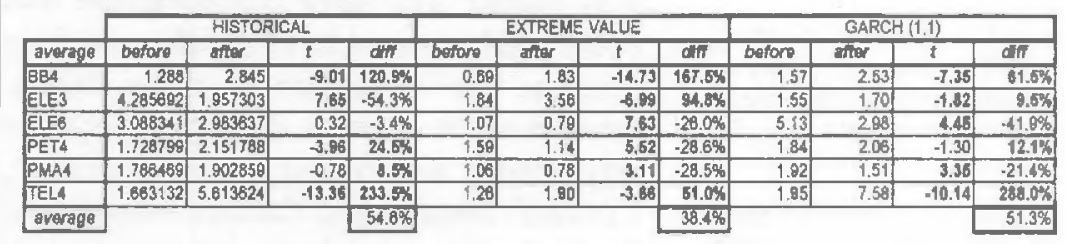

inconclusive. In the three cases analysed we have three shares showing a significant increase against the three other shares, which did not present the same characteristics. The same occurs in the two month time frame, the results are not conclusives.

If we focus on the average of these variations we have an indication of increase in the volatility of volatility. The result shows that volatility has become more stochastic for the investor. These averages reveal that the effect is greater in the smaller time frame, i.e., the effect tends
3. Tables 1 and 2 show the results attained in the three volatility cases. The results for each case are presented in the time frames before and after A statistic $t$ was applied to the two time frames referring to the equality test between the values and their variation based on the previous frame. In table 2 the averages of these variations are also presented. months were included. When we analyse the variability of this parameter we lose one month due to the fact that this analysis was based on 21 days of negotiations.
4. In the volatility analysis six 
Another condusion is that the change could affect the behaviour of the evaluation of models of contingency assets, since the influence of the introduction of options over the price of target asset is not taken into consideration when these models are built. Maybe this is one of the reasons for the distortions which could be observed among prices shown by the models and prices collected in the market.

to dissipate in the long run. This can mean that the effect of the option's listing tends to decrease with time.

The objective of this study was to identify changes in the behaviour of the volatility of shares in the Brazilian market when options were issued. An event study was developed on six shares over which options were issued in the period between 1990 and 1993. The results show a decrease in volatility and, therefore, in risk within the period of six months after the option was issued. The same phenomenon was observed by researchers in other markets such as the American and the Swiss. Studies such as those developed by Lee and Ohk ${ }^{5}$, Klemkosky and Maness ${ }^{6}$, Conrad ${ }^{7}$, Bruand and Gibson-Asner ${ }^{8}$, and Damadoran and Subrahmanyam ${ }^{9}$ unanimously report a decrease in volatility when options are issued.
Simultaneously, we noticed an indication of increase in the volatility of volatility of the underlying assets over which options were issued. This increase can also be found in studies about other countries as, for example, in Bruand and Gibson-Asner ${ }^{10}$. If our observation is corroborated by other studies the conclusion is that volatility becomes more stochastic when options are issued. The fact deserves consideration due to its importance in the development of models which describe the volatility of assets.

As a suggestion for new research we could mention the identification of facts which determine considerable changes in structuring the process which generates the volatility of financial assets. In an unstable economy, such as the Brazilian one, interesting results should be obtained. This analysis could also help to explain some big variations in volatility observed in table 1. An analysis of cause based on a set of dummy variables describing different levels of influence intensity could be an interesting way.

As a general conclusion to the study we could state that the introduction of options in the Brazilian market could benefit the investor since the risks of the target asset could be reduced. Another conclusion is that the change could affect the behaviour of the evaluation of models of contingency assets, since the influence of the introduction of options over the price of target asset is not taken into consideration when these models are built. Maybe this is one of the reasons for the distortions observed among prices shown by the models and prices collected in the market.

8. BRUAND, M., GIBSONASNER, R. Options, futures and stock market interactions: empirical evidence from the Swiss stock market. Manuscrito. Ecole des HEC. Suíça: Université de Lausanne, 1995.

9. DAMADORAN, A., SUBRAHMANYAM, M. The effects of derivatives securities on the markets for the underlying assets in the United States. Financial Markets. Institutions and Instruments. NY, USA: Willey, 1992.

10. BRUAND, M., GIBSONASNER, R. Options, futures and stock market interactions.. Op. cit.

\section{BIBLOOGRAFIA COMPLEMENTAR}

ENDERS, S. Applied econometric time series. NY, USA: Wiley, 1995.

GIBSON, R. L'évaluation des options. França: Presse Universitaire de France, 1993.

PARKINSON, M. The extreme value method for estimating the variance of the rate of return. Journal of Business, Chicago, v. 53, n. 1, p. 61-5, 1980.

SHARPE, W. F, ALEXANDER, G. J., BAILEY, J. V. Investments. 5. ed. NY, USA: Prentice Hall, 1995. 